\title{
Synthesis and Spectroscopic Properties of Quinazolinedione Derivatives
}

\author{
Fatma E.M. El-Baih, Safya B.A. Bakari and Abdullah A. Hijazi \\ Women Students Medical Studies \& Sciences Sections \\ College of Science, Chemistry Department \\ King Saud University, Riyadh, Saudi Arabia
}

\begin{abstract}
Treatment of anthranilic acid 1 or 3-amino 2-naphthoic acid 5 with butyl isocyanate in THF led to the formation of the ureido derivatives $\mathbf{3}$ and $\mathbf{7}$ respectively, which were cyclized to the corresponding diones $\mathbf{4}$ and $\mathbf{8}$ by refluxing in DMF, while the treatment of $\mathbf{1}$ or $\mathbf{5}$ with butyl isocyanate in DMF afforded the same diones $\mathbf{4}$ and 8 respectively. Treatment of 2,4-Bis (trimethylsilyloxy) quinazoline 9 with 1-O-acetyl-2,3,5-tri-O-benzoyl- $\beta$-D-ribofuranosyl)quinazoline- 2,4(1H-3H)-dione 11. Debenzolation led to the free nucleoside 12. Structural proofs of the prepared compounds are based on spectroscopic methods.
\end{abstract}

\section{Introduction}

Recently, there has been a flurry of activities in the synthesis of pyrimidine derivatives, especially pyrimidine based nucleosides ${ }^{[1-3]}$, due to their proven biological activity and medicinal utility. Substituted uracils and their nucleosides, in addition to isoguanine nucleosides, are of immense biological significance because of their use in the chemotheraphy of cancer ${ }^{[4-7]}$, e.g. 5-fluorouracil (FU), 5-fluoro-2 ${ }^{\prime}$-deoxyuridine (FUDR) and viral diseases ${ }^{[8-12]}$ e.g. trifluorothymidine ( $\left.\mathrm{F}_{3} \mathrm{TDR}\right)$, E-5-(2-bromovinyl-2'-deoxyuridine) (BVDU), 3'azido-3'deoxythymidine (ATZ), 1-(2'-deoxy-2'-fluoro- $\beta$-D-arabinofuranosyl)5-methyluracil (FMAU) and 5-(2-chloroethyl)-2'-deoxyuridine (CEDU), BVDU, FMAU and CEDU effectively inhibit herpes simplex virus (HSV-1) and varicella zoster virus replication in vitro ${ }^{[8,13-16]}$. The nucleoside FMAU showed activity against leukemic cells ${ }^{[17]}$ and AZT is an anti-AIDS compound ${ }^{[18]}$. Moreover, some quinazolinedione derivatives showed hypotensive activities on 
relaxing effects of the blood vessels ${ }^{[19]}$. Benzoquinolinedione derivatives are also of biological usefulness ${ }^{[20]}$. Owing to these diverse activities of pyrimidines and pyrimidines-based nucleosides were were interested to synthesize substituted quinazoline2-,4-dione, benzo [g] quinazoline2,4-dione and quinazoline2,4-dione nucleosides which might have biological activities.

\section{Results and Discussion}

Quinazoline-2,4(1H,3H)-dione 2 was prepared by fusing anthranilic acid and urea at $140-150^{\circ} \mathrm{C}$ in low yield $(30 \%)^{[21]}$. However using potassium cyanate method provide higher yield $(82 \%)^{[22]}$. Benzo[g]quinazoline-2,4(1H,3H)-dione $\mathbf{6}$ could not be isolated by the previous methods. The structure of $\mathbf{2}$ was further confirmed by ${ }^{1} \mathrm{H}$ NMR (Table 1), ${ }^{13} \mathrm{C}$ NMR (Table 2) and MS spectra data. The mass spectrum showed the molecular ion peak $\left[\mathrm{M}^{+}\right]$at $\mathrm{m} / z$ (abundance \%) $=$ 162 (100), which fragmented according retro Diels Alder (RDA) giving a fragment at $m / z=119(90 \%)$ as shown:<smiles>O=C1CC2CCCC(C2)N1</smiles>

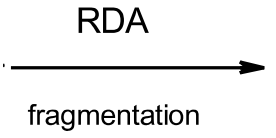

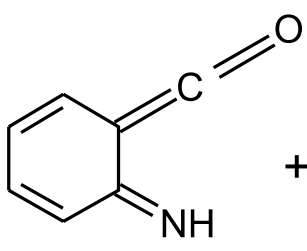

$$
m / z=119(90 \%)
$$

Treatment of anthranilic acid with butyl isocyanate and refluxing in THF afforded the ureido derivative 3 which was then cyclized by refluxing in DMF giving 4 in $42 \%$ yield, whereas refluxing a mixture of anthranilic acid and butyl isocyanate in DMF led to 4 in $64 \%$ yield $^{[23]}$ (Scheme 1). The mass spectrum of 3 and 4 showed the molecular ion peaks $\left[\mathrm{M}^{+}\right]$at $m / z$ (abundance \%) $=236(15)$ and 218 (31) respectively. The general fragmentation patterns proposed for $\mathbf{2 , 3}$ and $\mathbf{4}$ are designed in (Schemes 2, 3 and 4 respectively) ${ }^{[24]}$.

Similarly compounds $\mathbf{7}$ and $\mathbf{8}$ were prepared and their fragmentation patterns were as 3 and 4. Compounds 3, 4, 7 and 8 were further characterized by IR, ${ }^{1} \mathrm{H}$ NMR, ${ }^{13} \mathrm{C}$ NMR and elementary analyses (refer to experimental part). It is noticed that the methylene protons adjacent to $\mathrm{NH}$ in the ureido derivatives $3 \& 7$ appeared as quartet due to splitting by the $\mathrm{NH}$ proton and the other adjacent methylene protons by the same coupling constant, while in the cyclized compounds $4 \& 8$, it appeared as triplet due to splitting by the adjacent methylene protons only. 
TABLE 1. IR and ${ }^{1} \mathrm{H}$ NMR data of compounds (2, 3, 4, 7 and 8).

\begin{tabular}{|c|c|c|}
\hline $\begin{array}{l}\text { Comp. } \\
\text { no. }\end{array}$ & $\operatorname{IR}\left(\mathrm{cm}^{-1}\right)$ & $\begin{array}{c}{ }^{1} \mathrm{H} \text { NMR in DMSO-d }{ }_{6} \text { or } \mathrm{CDCl}_{3} * \\
(\delta \text { in ppm, } J \text { in } \mathrm{Hz})\end{array}$ \\
\hline 2 & $\begin{array}{l}3228,3171(2 \mathrm{NH}) ; \\
1703(\mathrm{CO} \text { at position } 4) ; \\
1674(\mathrm{CO} \text { at position } 4) .\end{array}$ & $\begin{array}{l}11.40 \text { br.s }(\mathrm{NH}), 11.28 \text { br.s }(\mathrm{NH}) \\
7.87\left(1 \mathrm{H} ; \mathrm{dd} ; J=8.0,1.8 ; \mathrm{C}_{5}-\mathrm{H}\right) \\
7.62\left(1 \mathrm{H} ; \mathrm{td} ; J=8.0,1.8 ; \mathrm{C}_{7}-\mathrm{H}\right) \\
7.18-7.12\left(2 \mathrm{H}, \mathrm{m}, \mathrm{C}_{6}-\mathrm{H} \& \mathrm{C}_{8}-\mathrm{H}\right)\end{array}$ \\
\hline 3 & $\begin{array}{l}3550,3309(2 \mathrm{NH}) ; \\
3350-2558(\text { carboxylic } \mathrm{OH}) ; \\
\text { 2957, 2931, 2871, }\left(\mathrm{CH}_{2}, \mathrm{CH}_{3}\right) ; \\
1684(\text { carboxylic } \mathrm{CO}) ; \\
1655 \text { (amidic CO). }\end{array}$ & 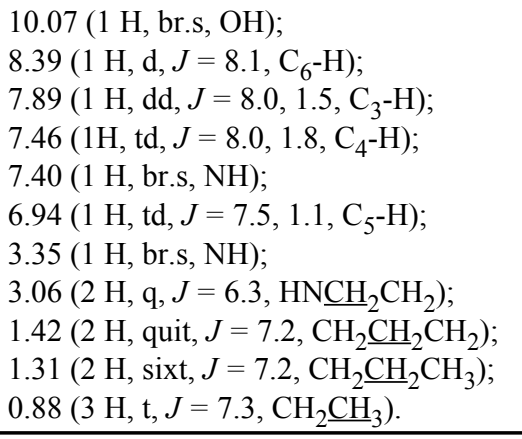 \\
\hline 4 & $\begin{array}{l}3190(\mathrm{NH}) \\
2953,2937,2871\left(\mathrm{CH}_{2}, \mathrm{CH}_{3}\right) \\
1716(\mathrm{CO} \text { at position } 4) ; 1663 \\
(\mathrm{CO} \text { at position } 2)\end{array}$ & $\begin{array}{l}10.52(1 \mathrm{H}, \text { br. s, NH); } \\
8.14\left(1 \mathrm{H}, \mathrm{d}, J=7.4, \mathrm{C}_{5}-\mathrm{H}\right) ; \\
7.61\left(1 \mathrm{H}, \mathrm{t}, J=8.0, \mathrm{C}_{7}-\mathrm{H}\right) ; \\
7.26\left(1 \mathrm{H}, \mathrm{t}, J=8.0, \mathrm{C}_{6}-\mathrm{H}\right) ; \\
7.14\left(1 \mathrm{H}, \mathrm{d}, J=8.0, \mathrm{C}_{8}-\mathrm{H}\right) ; \\
4.10\left(2 \mathrm{H}, \mathrm{t}, J=7.6, \mathrm{NCH}_{2} \mathrm{CH}_{2}\right) ; \\
1.71\left(2 \mathrm{H}, \text { quint, } J=7.4, \mathrm{CH}_{2} \mathrm{CH}_{2} \mathrm{CH}_{2}\right) ; \\
1.43\left(2 \mathrm{H}, \text { six, } J=7.4, \mathrm{CH}_{2} \underline{\mathrm{CH}}_{2} \mathrm{CH}_{3}\right) ; \\
0.98\left(3 \mathrm{H}, \mathrm{t}, J=7.4, \mathrm{CH}_{2} \underline{\mathrm{CH}}_{3}\right) .\end{array}$ \\
\hline 7 & $\begin{array}{l}3414,3304(2 \mathrm{NH}) \\
\text { 3354-2871 }(\text { carboxylic } \mathrm{OH}) \\
\text { 2958, } 2929,2871\left(\mathrm{CH}_{2}, \mathrm{CH}_{3}\right) \\
1680 \text { (carboxylic } \mathrm{CO}) \\
1657 \text { (amidic } \mathrm{CO})\end{array}$ & $\begin{array}{l}9.99(1 \mathrm{H}, \mathrm{br} . \mathrm{s}, \mathrm{OH}) \\
8.77\left(1 \mathrm{H}, \mathrm{s}, \mathrm{C}_{1}-\mathrm{H}\right) ; \\
8.61\left(1 \mathrm{H}, \mathrm{s}, \mathrm{C}_{4}-\mathrm{H}\right) ; \\
7.94\left(1 \mathrm{H}, \mathrm{d}, J=8.0, \mathrm{C}_{8}-\mathrm{H}\right) ; \\
7.75\left(1 \mathrm{H}, \mathrm{d}, J=8.0, \mathrm{C}_{5}-\mathrm{H}\right) ; \\
7.54\left(1 \mathrm{H}, \mathrm{t}, J=7.1, \mathrm{C}_{6}-\mathrm{H}\right) ; \\
7.37\left(1 \mathrm{H}, \mathrm{t}, J=7.1, \mathrm{C}_{7}-\mathrm{H}\right) ; \\
3.35(1 \mathrm{H}, \mathrm{br} . \mathrm{s}, \mathrm{NH}) \\
3.10\left(2 \mathrm{H}, \mathrm{q}, J=6.5, \mathrm{HNCH}_{2} \mathrm{CH}_{2}\right) ; \\
1.46\left(2 \mathrm{H}, \mathrm{quit}, J=7.3, \mathrm{CH}_{2} \mathrm{CH}_{2} \mathrm{CH}_{2}\right) ; \\
1.34\left(2 \mathrm{H}, \mathrm{sixt}, J=7.2, \mathrm{CH}_{2} \frac{\mathrm{CH}_{2}}{\mathrm{CH}_{3}}\right) ; \\
0.91\left(3 \mathrm{H}, \mathrm{t}, J=7.3, \mathrm{CH}_{2} \underline{\mathrm{CH}}_{3}\right) .\end{array}$ \\
\hline 8 & $\begin{array}{l}3179(\mathrm{NH}) \\
2958,2929,2875,\left(\mathrm{CH}_{2}, \mathrm{CH}_{3}\right) \\
1715(\mathrm{CO} \text { at position } 4) ; 1655 \\
(\mathrm{CO} \text { at position } 2) .\end{array}$ & $\begin{array}{l}8.76\left(2 \mathrm{H}, \mathrm{s}, \mathrm{C}_{5}-\mathrm{H} \& \mathrm{C}_{10}-\mathrm{H}\right) \\
7.97\left(1 \mathrm{H}, \mathrm{d}, J=8.3, \mathrm{C}_{6-} \mathrm{H}\right) \\
7.80\left(1 \mathrm{H}, \mathrm{d}, J=8.5, \mathrm{C}_{9}-\mathrm{H}\right) \\
7.59\left(1 \mathrm{H}, \mathrm{t}, J=7.0, \mathrm{C}_{8}-\mathrm{H}\right) \\
7.45\left(1 \mathrm{H}, \mathrm{t}, J=7.6, \mathrm{C}_{7}-\mathrm{H}\right)\end{array}$ \\
\hline
\end{tabular}


TABle 1. Contd.

\begin{tabular}{|c|c|c|}
\hline $\begin{array}{c}\text { Comp. } \\
\text { no. }\end{array}$ & $\operatorname{IR}\left(\mathrm{cm}^{-1}\right)$ & $\begin{array}{c}{ }^{1} \mathrm{H} \text { NMR in DMSO-d } 6 \text { OR } \mathrm{CDCl}_{3} * \\
(\delta \text { in ppm, } J \text { in } \mathrm{Hz})\end{array}$ \\
\hline & & $\begin{array}{l}7.38(1 \mathrm{H}, \text { br. s, NH}) ; \\
4.13\left(2 \mathrm{H}, \mathrm{t}, J=7.5, \mathrm{NCH}_{2} \mathrm{CH}_{2}\right) ; \\
1.73\left(2 \mathrm{H}, \text { quint, } J=7.8, \mathrm{CH}_{2} \mathrm{CH}_{2} \mathrm{CH}_{2}\right) ; \\
1.45\left(2 \mathrm{H}, \text { sixt, } J=7.8, \mathrm{CH}_{2} \underline{\mathrm{CH}}_{2} \mathrm{CH}_{3}\right) ; \\
0.99\left(3 \mathrm{H}, \mathrm{t}, J=7.3, \mathrm{CH}_{2} \underline{\mathrm{CH}}_{3}\right) .\end{array}$ \\
\hline
\end{tabular}

TABLE $2 .{ }^{13} \mathrm{C}$ NMR data of compounds $(2,3,4$ and 7$)$ in DMSO-D D $_{6}(\delta$-values in ppm).

\begin{tabular}{|c|c|c|c|c|c|c|c|c|c|c|c|c|c|c|c|}
\hline \multirow{2}{*}{$\begin{array}{c}\text { Comp. } \\
\text { no. }\end{array}$} & \multicolumn{10}{|c|}{ Aromatic carbons } & \multicolumn{4}{|c|}{ Butyl carbons } & \multirow{2}{*}{$\begin{array}{l}\text { Carbonyl } \\
\text { carbons }\end{array}$} \\
\hline & $\mathrm{C}_{1}$ & $\mathrm{C}_{2}$ & $\mathrm{C}_{3}$ & $\mathrm{C}_{4}$ & $\mathrm{C}_{4 \mathrm{a}}$ & $\mathrm{C}_{5}$ & $\mathrm{C}_{6}$ & $\mathrm{C}_{7}$ & $\mathrm{C}_{8}$ & $\mathrm{C}_{8 \mathrm{a}}$ & $\mathrm{C}_{1}$ & $\mathrm{C}_{2}$ & $\mathrm{C}_{3}$ & $\mathrm{C}_{4^{\prime}}$ & \\
\hline 2 & - & - & - & - & 121.1 & 129.0 & 113.0 & 132.5 & 112.0 & 140.5 & - & - & - & - & $\begin{array}{l}151.1 \text { (HNCONH), } \\
162.5(\mathrm{CONH}) .\end{array}$ \\
\hline 3 & 119.7 & 143.9 & 114.8 & 134.3 & - & 120.4 & 131.5 & - & - & - & $*$ & 32.2 & 20.1 & 14.3 & $\begin{array}{l}155.2 \text { (HNCONH), } \\
170.1(\mathrm{COOH}) .\end{array}$ \\
\hline 4 & - & - & - & - & 123.4 & 128.4 & 115.1 & 135.0 & 114.7 & 138.7 & 41.0 & 30.1 & 20.3 & 13.9 & $\begin{array}{l}151.3 \text { (HNCOBu), } \\
162.5 \text { (CONBu). }\end{array}$ \\
\hline 7 & 133.3 & 117.1 & 138.8 & 115.3 & 136.5 & 127.2 & 127.4 & 124.9 & 129.5 & ** & * & 32.3 & 20.2 & 14.3 & $\begin{array}{l}155.5(\mathrm{HNCONH}), \\
170.0(\mathrm{COOH}) .\end{array}$ \\
\hline
\end{tabular}

*Within the solvent peaks.

**Within the base line.

$$
\begin{array}{|l|ll|}
\hline & \mathrm{R} & \mathrm{R} \\
\hline 1 & \mathrm{H} & \mathrm{H} \\
\hline 5 & & \\
\hline
\end{array}
$$

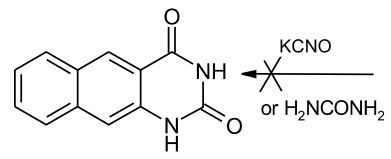

6<smiles>[R]C=CC(=O)O</smiles><smiles>O=[N+]([O-])O[Na]</smiles>
$1 \mathrm{BuNCO} / \mathrm{DMF}$ $\mathrm{BuNCO} / \mathrm{THF}$<smiles>C1CCCCC1</smiles>

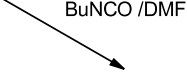<smiles>O=c1[nH]c(=O)c2ccccc2[nH]1</smiles><smiles>[R]c1cc(NC(=O)OCCCC)c(C(=O)O)cc1[R]</smiles><smiles>[R]c1cc2[nH]c(=O)n(C(C)(C)C)c(=O)c2cc1[R]</smiles>

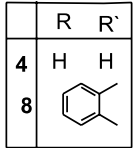

Scheme 1 


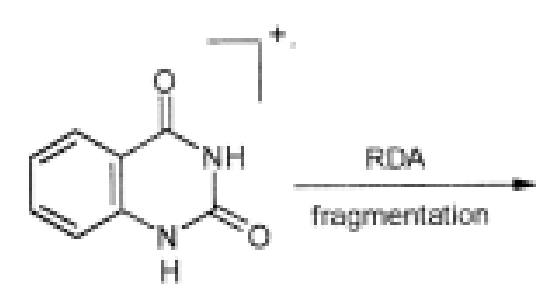<smiles>C[C+](C)CCCCCC(=O)N=O</smiles>

$$
\begin{gathered}
m \sqrt{2}=162(100) \\
\mathrm{C}_{6} \mathrm{H}_{6} \mathrm{~N}_{2} \mathrm{O}_{2}
\end{gathered}
$$
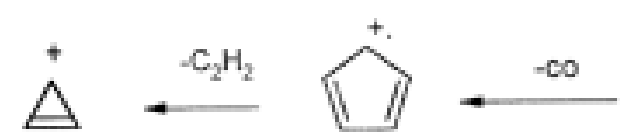
$m / z=119(90)$ $\mathrm{C}_{7} \mathrm{H}_{9} \mathrm{NO}$ $m i z=39(30)$ $\mathrm{C}_{3} \mathrm{H}_{3}$ $m v z=64(60)$ $\mathrm{C}_{5} \mathrm{H}_{4}$

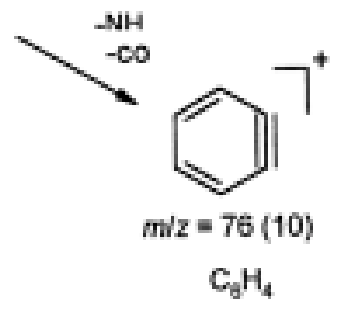
()$=$ Abundance $\%$.

Scheme 2

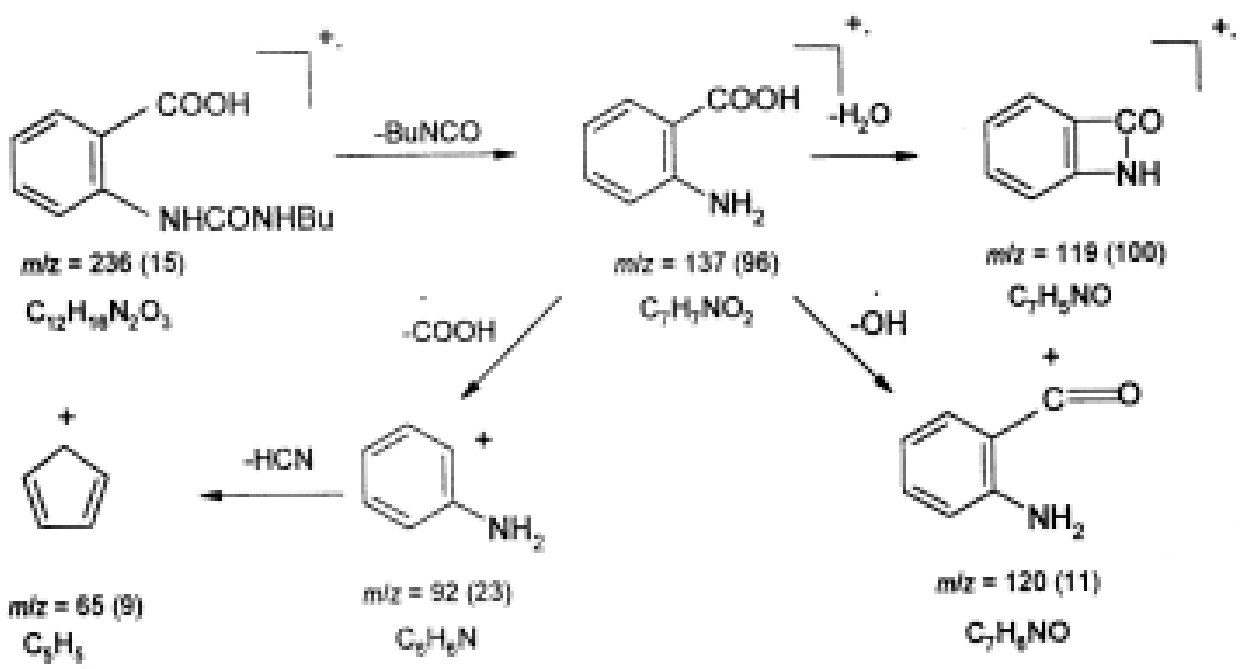

() = Abundance \%. 


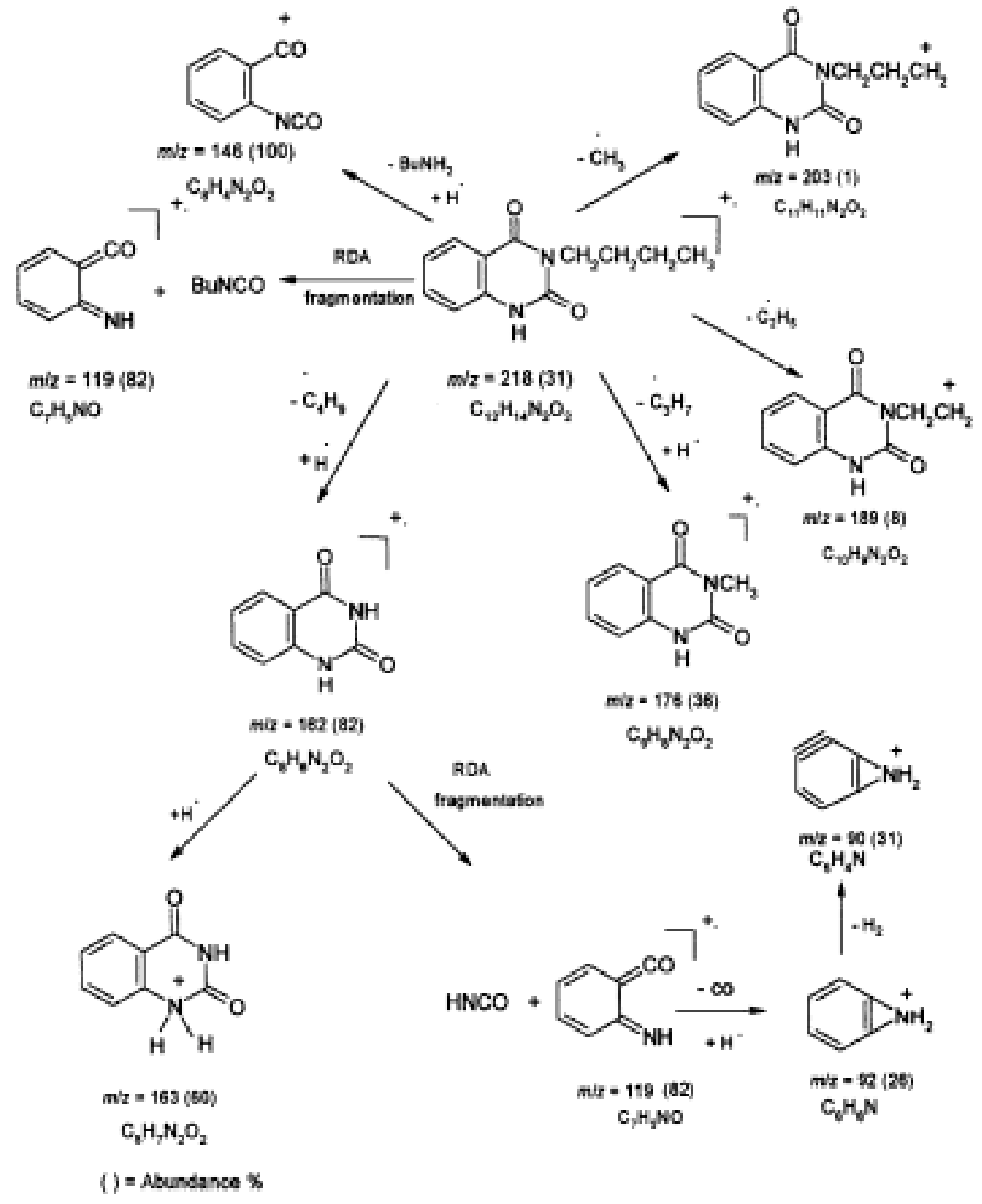

Scheme 4 
The use of trimethylsilyl derivative of nitrogen heterocycles in nucleoside synthesis was first introduced by Birkofer, et al., in a novel synthesis of 3ribofuranosyl uric acid ${ }^{[25]}$. Fusion of 2,4-bis(trimethylsilyloxy) pyrimidine with 2,3,5-tri-O-benzoylribofuranosyl chloride which was employed by Nishimura, Shimizu and Iwai yielded uridine in $35 \%$ yield ${ }^{[26]}$. Initial attempts to condense trimethylsilyloxypyrimidines and acetohalo sugars directly in boiling benzene were unsuccessful ${ }^{[27]}$ while the use of polar solvents and milder reaction conditions has been more successful ${ }^{[28]}$. Stout and Robins prepared 1- $(\beta$-Dribofuranosyl)-2,4-quinazolinedione, starting from quinazoline-2,4-dione, which was silylated by trimethylchlorosilane in the presence of toluene and trimethylamine, when glycosylated with 2,3,5-tri-O-benzoylribofuranosyl bromide in dry acetonitrile and finally debenzoylated ${ }^{[29]}$.

In our present study, treatment of 2 with hexamethyldisilazane $\left(\mathrm{Me}_{3} \mathrm{Si}\right.$ $\mathrm{NHSiMe}_{3}, \mathrm{HMDS}$ ) in the presence of a few crystals of ammonium sulfate gave 2,4-bis(trimethylsilyloxy)quinazoline 9. Treatment of 9 with 1-O-acetyl-2,3,5tri-O-benzoyl- $\beta$-D-ribofuranose 10 in dry 1,2-dichloro-ethane and in the presence of trimethylsilyl triflate $\left(\mathrm{Me}_{3} \mathrm{SiOSO}_{2} \mathrm{CF}_{3}\right)$, provided 11. Debenzoylation to the free ribosides $\mathbf{1 2}$ in $82 \%$ yield was performed by sodium methoxide in methanol (Scheme 5). Structural assignments of $11 \& 12$ were based on ${ }^{1} \mathrm{H}$ NMR (Table 3), ${ }^{13} \mathrm{C}$ NMR (see experimental part \& Fig. 1) and MS spectral data (look at experimental part). The structure of the nucleoside $\mathbf{1 2}$ was also proved by ${ }^{1} \mathrm{H}_{-}{ }^{13} \mathrm{C}$ HETCOR experiment.
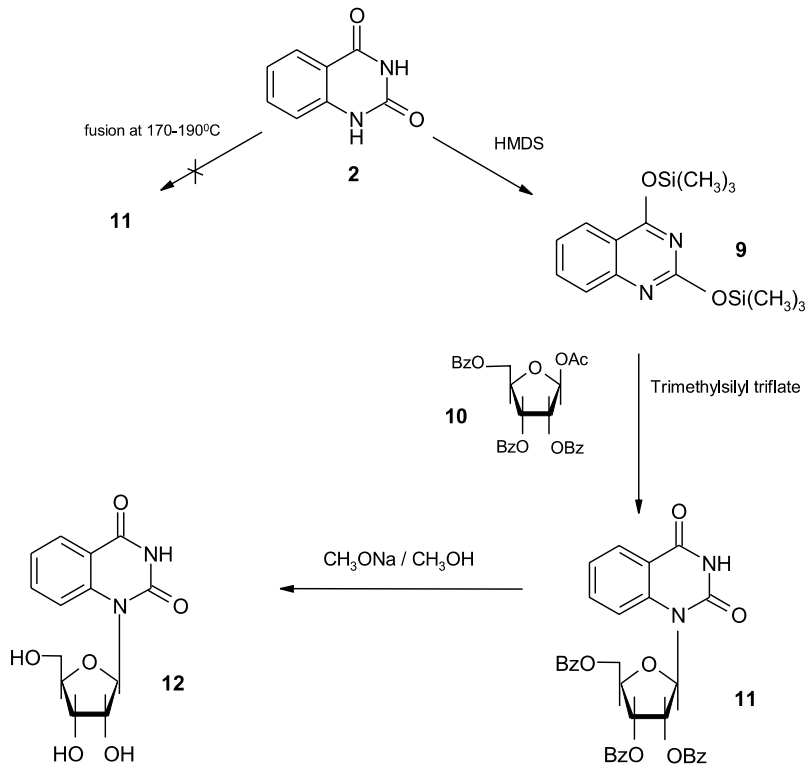

Scheme 5 


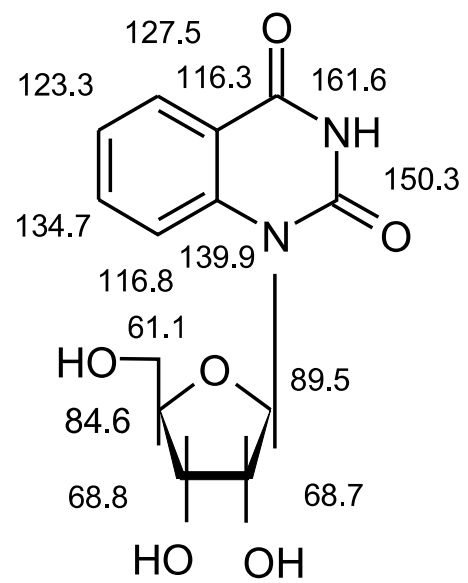

FIG. $1 .{ }^{13} \mathrm{C}$ NMR $\delta$-values of 12 .

TABLE 3. ${ }^{1} \mathrm{H}$ NMR data of compounds $(11$ and 12$)$ in DMSO- $\mathrm{d}_{6}$ or $\mathrm{CDCl}_{3} *(\delta$-values in ppm, $J$ values in $\mathrm{Hz}$ ).

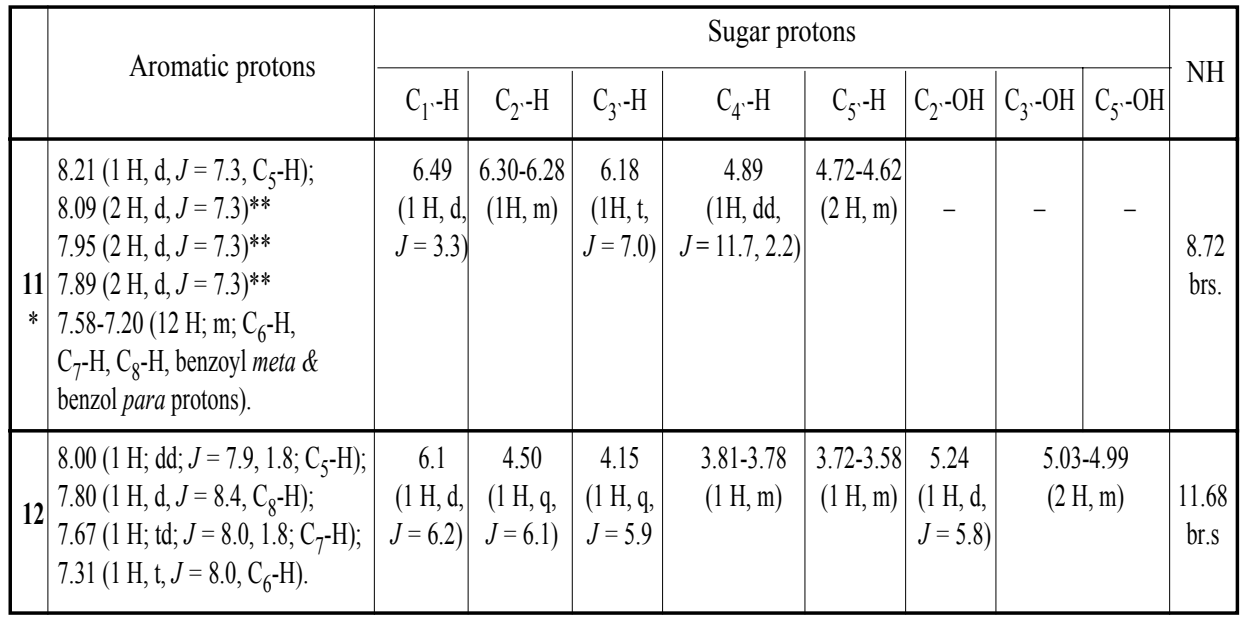

** benzoyl ortho protons.

The configuration of the glycosidic linkages can be assigned readily from the ${ }^{1} \mathrm{H}$ NMR spectra in $\mathrm{CDCl}_{3}$ and DMSO-d $\mathrm{d}_{6}$, respectively, to be the $\beta$ - anomer as indicated by an upfield chemical shift of $1{ }^{\prime}-\mathrm{H}$. However, this is different from the chemical shift observed in the lower field, which was recognized for $\alpha$-anomer of other ribofuranosides ${ }^{[30,31]}$. Furthermore, in almost all cases exhibited, a very distinct separation and coupling of the sugar protons providing the assigned configuration conclusively. 
The mass spectrum of 11 was characterized by a fragment at $m / z=484$ [M122] due to loss of benzoic acid from the molecular ion. The base peak is due to the benzoyl ion which appeared at $m / z=105$.

The mass spectrum of $\mathbf{1 2}$ showed a weak molecular ion peak at $\mathrm{m} / \mathrm{z}=\mathbf{2 9 4}$, which lost the sugar part to afford a fragment at $\mathrm{m} / \mathrm{z}$ (abundance \%) $=162(100)$ that represented the base peak, then fragmented according to RDA to give a fragment at $m / z$ (abundance \%) $=119(30)$. Fragmentation at the glycosidic linkage gave also a fragment of the ribofuranose ion at $\mathrm{m} / \mathrm{z}$ (abundance \%) $=134$ (2).

An attempt to prepare $\mathbf{1 1}$ by dry fusion method was unsuccessful ${ }^{[32]}$.

\section{Experimental}

Melting points were determined on a Tottoli capillary melting point apparatus and are uncorrected. IR spectra were run for $\mathrm{KBr}$ discs on Perkin Elmer FT spectrophotometer $1000 .{ }^{1} \mathrm{H}$ and ${ }^{13} \mathrm{C}$ NMR spectra were taken on either a JEOL ECP 400 NMR spectrometer operating at $400 \mathrm{MHz}$ or on a JEOL ECP 300 NMR spectrometer operating at $300 \mathrm{MHz}$ in DMSO-d $\mathrm{d}_{6}\left(\right.$ or $\left.\mathrm{CDCl}_{3}\right)$ with TMS as internal standard. Chemical shift are given in $\delta$ ppm and coupling constants $(J)$ are given in Hz. Electron impact (EI) MS spectra were carried on Shimadzu GCMSQP5050A spectrometer, DB-1 glass column $30 \mathrm{~m}, 0.25 \mathrm{~mm}$, ionization energy $70 \mathrm{eV}$, at Chemistry Department, College of Science, King Saud University. Microanalyses were carried out at the central laboratory of King Saud University, Women Students, Medical Studies and Science Sections.

\section{Quinazoline-2,4(1H, 3H)-dione 2}

It was prepared according to ref. ${ }^{[21,22]}$. It was characterized by its m.p. (above $300^{\circ}$ ) IR and ${ }^{1} \mathrm{H}$ NMR (400 MHz, DMSO-d 6 ) $\left(\right.$ Table 1) ${ }^{13} \mathrm{C}$ NMR (Table 2) and MS (Scheme 2).

\section{$o$-N`-Butylureidobenzoic acid 3}

A mixture of anthranilic acid $(6.85 \mathrm{~g}, 0.05 \mathrm{~mol})$, butyl iosocyanate $(5.6 \mathrm{ml}$, $4.96 \mathrm{~g}, 0.05 \mathrm{~mol})$ and THF (50 ml) was refluxed for $5 \mathrm{~h}$. After cooling to room temperature, sq. $\mathrm{NH}_{4} \mathrm{Cl}(10 \%, 200 \mathrm{ml})$ was added. The precipitate appeared was filtered, washed with water, dried and recrystallized from aq. ethanol to give 3, as pale brown fine crystals, (yield $79 \%$ ), m.p. $146-148^{\circ} \mathrm{C}$, IR and ${ }^{1} \mathrm{H}$ NMR (400 MHz, DMSO-d 6 ) (Table 1), ${ }^{13} \mathrm{C}$ NMR (Table 2) and MS (Scheme 3).

\section{3-Butyl-quinazoline-2,4(1H,3H)-dione 4}

Prepared by two methods: 


\section{Method A}

A mixture of 3 (2.36 g, $0.01 \mathrm{~mol})$ and DMF (50 ml) was refluxed for $2 \mathrm{~h}$. After cooling to room temperature, aq. $\mathrm{NH}_{4} \mathrm{Cl}(70 \mathrm{ml}, 10 \%)$ was added. The precipitate appeared was filtered, washed with water, dried and recrystallized from aq. ethanol to give 4 as pale brown fine crystals, (yield 42), m.p. $151-152^{\circ} \mathrm{C}$.

\section{Method B}

A mixture of anthranilic acid $(6.86 \mathrm{~g}, 0.05 \mathrm{~mol})$, butyl isocyanate $(5.57 \mathrm{~m}$, $4.96 \mathrm{~g}, 0.05 \mathrm{~mol}$ ) and DMF (30 ml) was refluxed for $2 \mathrm{hr}$. After cooling to room temperature, sq. $\mathrm{NH}_{4} \mathrm{Cl}(200 \mathrm{ml}, 10 \%)$ was added. The precipitate was filtered, washed with water, dried and recrystallized from aq. ethanol, (yield, 64\%), m.p. $151-152^{\circ} \mathrm{C}$. IR and ${ }^{1} \mathrm{H}$ NMR $\left(300 \mathrm{MHz}, \mathrm{CDCl}_{3}\right.$ ) (Table 1), ${ }^{13} \mathrm{C}$ NMR (Table 2) and MS (Scheme 4). $\mathrm{C}_{12} \mathrm{H}_{14} \mathrm{~N}_{2} \mathrm{O}_{2}$; Calcd: $\mathrm{C}, 66.06 ; \mathrm{H}, 6.42 ; \mathrm{N}, 12.84$. found: $\mathrm{C}, 66.50 ; \mathrm{H}, 6.00 ; \mathrm{N}, 12.90$

\section{3-N’-Butylureido-2-naphthoic acid 7}

Prepared by the same procedure as compound 3. Recrystallized from ethyl acetate (yield 94\%), m.p. $177-179^{\circ} \mathrm{C}$. It was characterized by: IR and ${ }^{1} \mathrm{H}$ NMR (400 MHz, DMSO-d d $_{6}$ (Table 1), ${ }^{13} \mathrm{C}$ NMR (Table 2) and MS $\mathrm{m} / \mathrm{z}$ (abundance

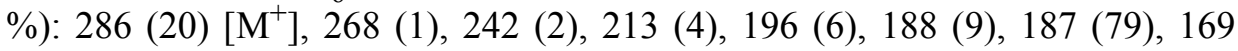
(100) 142 (29), 114 (14), 98 (3) and 70 (8). $\mathrm{C}_{16} \mathrm{H}_{18} \mathrm{~N}_{2} \mathrm{O}_{3}$; Calcd: C, 67.12; H, $6.34 ; \mathrm{N}, 9.78$ found: $\mathrm{C}, 66.92 ; \mathrm{H}, 6.68 ; \mathrm{N}, 9.61$.

\section{3-Butylbenzo[g]quinazoline-2,4(1H,3H)-dione 8}

Prepared by the same procedure as compound 4 . Recrystallized from aq. ethanol, yield: $38 \%$ (methanol $A$ ), 50\% (methanol B), m.p. $267-269^{\circ} \mathrm{C}$. It was characterized by : IR and ${ }^{1} \mathrm{H}$ NMR $\left(300 \mathrm{MHz}, \mathrm{CDCl}_{3}\right.$ ) (Table 1) and MS $m / z$ (abundance \%): 268 (62) $\left[\mathrm{M}^{+}\right], 251$ (7), 239 (4), 226 (24), 212 (100), 196 (52), 169 (69), 142 (29) and 141 (9). $\mathrm{C}_{16} \mathrm{H}_{16} \mathrm{~N}_{2} \mathrm{O}_{2}$; Cald: $\mathrm{C}, 71.64 ; \mathrm{H}, 5.97 ; \mathrm{N}, 10.45$. found: $\mathrm{C}, 71.60 ; \mathrm{H}, 5.80 ; \mathrm{N}, 10.50$.

\section{2,4-Bis(trimethylsilyloxy)quinazoline}

A suspension of $2(4.7 \mathrm{~g}, 0.029 \mathrm{~mol})$ and a few crystals of ammonium sulfate in hexamethyldisilazane (HMDS) $(25 \mathrm{ml})$ was refluxed under anhydrous conditions with stirring for $24 \mathrm{~h}$ to form a clear solution. The excess of HMDS was distilled off in vacuum to yield $\mathbf{9}$ quantitatively as colorless oil. The material is pure enough for further reactions. 


\section{1-(2`,3`,5 -tri-O-benzoyl-?-D-ribofuranosyl)-quinazoline-2,4(1H,3H)-dione 11}

A solution of 1-O-acetyl-2,3,5-tri-O-benzoyl- $\beta$-D-ribofuranose 10 (14.6 g, $0.029 \mathrm{~mol})$ in dry 1,2 -dichloroethane $(10 \mathrm{ml})$ was added to 9 , then a solution of trimethylsilyl triflate $(2.4 \mathrm{ml})$ in dry 1,2-dichloroethane $(10 \mathrm{ml})$ was added with continuous stirring. The reaction mixture was stirred at room temperature for 24 $\mathrm{h}$, then treated subsequently three times with $1 \mathrm{~N}$ sodium bicarbonate solution $(100 \mathrm{ml})$ and twice with water. The organic layer was dried over anhydrous sodium sulfate, evaporated to dryness under vacuum $(20 \mathrm{~mm} \mathrm{Hg})$ to yield an amorphous foam $(9.9 \mathrm{~g}, 56 \%)$ of 11. It was separated on silica gel columns (50 $\times 4 \mathrm{~cm})$ by chromatography in 1,2-dichloroethane / ethyl acetate $(25 / 1)$. Then recrystallized from ethanol m.p. $168-170^{\circ} \mathrm{C} .{ }^{1} \mathrm{H} \mathrm{NMR}\left(400 \mathrm{MHz}, \mathrm{CDCl}_{3}\right)$ data are in (Table 1), ${ }^{13} \mathrm{C}$ NMR $\delta: 166.3,165.5,165.3,161.4$, and 149.6 (carbonyl carbons); 140.2-114.8 (15 lines, aromatic carbons); $89.3\left(\mathrm{C}_{1}\right), 79.5\left(\mathrm{C}_{4}\right), 73.1$ $\left(\mathrm{C}_{3}\right), 70.1\left(\mathrm{C}_{2}\right), 63.5\left(\mathrm{C}_{5}\right)$ (sugar carbons). $\mathrm{MS} m / z(\%): 484\left(\mathrm{M}-\mathrm{C}_{6} \mathrm{H}_{5} \mathrm{COOH}\right.$, 1), 445 (7), 363 (3), 241 (2), 201 (11), 162 (1), 122 (11), 105 (100), 77 (34) and 51 (12).

\section{1-( $\beta$-D-Ribofuranosyl)-quinazoline-2,4(1H,3H)-dione 12}

Compound 11 (1.7 g, $0.0028 \mathrm{~mol})$ was added to methanolic sodium methoxide solution (60 $\mathrm{mg}$ sodium in $200 \mathrm{ml}$ of absol. methanol) and then stirred for $24 \mathrm{~h}$ at room temperature. After addition of water $(20 \mathrm{ml})$ the solution was neutralized with acetic acid and evaporated to dryness. The residue was coevaporated three times with methanol $(20 \mathrm{ml})$, twice with methanol $(30 \mathrm{ml})$, then suspended in water $(30 \mathrm{ml})$, left overnight, filtered, washed with water, dried and recrystallized from ethanol (yield $82 \%$ ), m.p. $217-219^{\circ} \mathrm{C} .{ }^{1} \mathrm{H}$ NMR (400 MHz, DMSO-d 6 ) (Table 3). ${ }^{13} \mathrm{C}$ NMR $\delta$-values assignment are shown in (Fig 3). MS m/z (\%): 294 (0.13) $\left[\mathrm{M}^{+}\right], 162$ (100), 146 (11), 134 (2), 132 (11), 119 (30), 92 (10) and 73 (16). Anal. Calcd. for $\mathrm{C}_{13} \mathrm{H}_{14} \mathrm{~N}_{2} \mathrm{O}_{6}$ : C, 53.06; H, 4.80; N, 9.78. Found: C, 52.90; H, 5.10.

\section{References}

[1] Rajeev, K.G. and Broom, A.D., Org. Lett., 2 (23), 3595 (2000).

[2] Manfredini, S., Baraldi, P.G., Bazzanini, R., Simoni, D., Balzarini, J. and Clercq, E. De, Bioorganic \& Medicinal Chemistry Letters, 7 (2), 473 (1997).

[3] Urata, H., Miyagoshi, H., Kakuya, H., Tokumoto, H., Kawahata, T., Otake, T. and Akagi, M., Chem. Pharm. Bull., 46 (3), 458 (1998).

[4] Liebich, H.M., Lehmann, R., Di Stifano, C., Haring, H.U., Kim, J.H. and Kim, K.R., J. Chromatogr., A, 795, 388 (1998).

[5] Kim, J.H., Lee, S.J., Han, Y.B., Moon, J.J. and Kim, J.B., Arch. Pharmacol Res., 17, 115 (1994).

[6] Dziewiszek, K., Schinazi, R.F., Chao Chou, T., Long Su, T., Dzik, J.M., Rode, W. and Watanabe, K.A., Nucleosides \& Nucleotides, 13, (1-3), 77 (1994). 
[7] Heidelderger, C., Pyrimidine and Pyrimidine Antimetabolites in Cancer Medicine, p. 801 ed. Holland, J.F. and Frei, E., Lea and Febiger, Philadelphia (1984).

[8] Clercq, E. De, Descamps, J., Somer, P. De, Barr, P. J., Joses, A .S. and Walker, R.T., Proc. Natl. Acad. Sci. USA, 76, 2947 (1979).

[9] Heidelberger, C. and King, D.H., Antiviral Agents in Pharmacology and Therapeutics, p. 427, 6 ed. D. Shugar, Pergamon, Oxford, (1979).

[10] Mitsuya, H., Weinhold, K.J., Furman, P.A., St. Clair, M.H., Lehrman, S.N., Gallo, R.C., Bolognesi, D., Barry D.W. and Broder, S., Proc. Natl. Acad. Sci. USA, 82, 7096 (1985).

[11] Fischl, M.A., Richman, D.D., Grieco, M.H., Gottlieb, M.S., Volberdin, P.A., Laskin, O.L., Leedom, J.M., Groopman, J.E., Mildvan, D., Schooley, R.T., Jackson, G.G., Durack, D.T. and King, D.N., Engl. J. Med., 317, 185 (1987).

[12] Griengl, H., Bodenteich, M., Hayden, W., Wanek, E., Streicher, W., Stutz, P., Bachmayer, H.,Ghazzouli, I. and Rosenwirth, B., J. Med. Chem., 28, 1679 (1985).

[13] Clercq, E. De, Descamps, J., Ogata, M. and Shigeta, S., Antimicrob. Agents Chemother., 21, 33 (1982).

[14] Clercq, E. De and Rosenwirth, B., Antimicrob. Agents Chemother., 28, 246 (1985).

[15] Rosenwirth, B., Griengl, H., Wanek, E. and Clercq, E. De, Antiviral Res., suppl., 1, 21 (1985).

[16] Schinazi, R.F., Fox, J.J., Watanabe, K.A. and Nahmias, A., J. Antimicrob. Agents Chemother., 29, 7784 (1985).

[17] Chou, T.C., Burchenal, J.H., Schmid, F.A., Braun, T.J., Su, T.L., Watanabe, K.A., Fox, J.J. and Philips, F. S., Cancer Res., 42, 3957 (1985).

[18] Macilwain, C., Nature, 365, 378 (1993).

[19] Eguchi, Y., Sasaki, F., Sugimoto, A., Ebisawa, H. and Ishikawa, M., Chem. Pharm. Bull., 39 (7), 1753 (1991).

[20] Banasik, M., Komura, H., Shimoyama, M. and Ueda, K., J. Biol. Chem., 267, 1569 (1992).

[21] Brunel, S., Montginoul, C., Torreilles, E. and Giral, L., J. Heterocyclic Chem., 17, 235 (1980).

[22] Org. Syntheses, 79, II, ed. Blatt, A. H. John Wiley and Sons, Inc., New York (1943).

[23] Kobayashi, K., Tanaka, H., Takabatake, H., Kitamura,T., Nakahashi, R., Morikawa, O. and Konishi, H., Bull. Chem. Soc. Jpn., 72, 1071 (1999).

[24] Rama, N.H. and Hussain, M.T., J. Saudi Chem. Soc., 3 (1), 7 (1999).

[25] Birkofer, L., Ritter, A.R. and Kulthau, H.P., Angew. Chem., 75, 209 (1963).

[26] Nishimura, T., Shimizu, B. and Iwai, I., Chem. Pharm. Bull. (Tokyo), 11, 1470 (1963).

[27] Nishimura, T. and Iwai, I., Chem. Pharm. Bull. (Tokyo), 12, 357 (1964).

[28] Wittenberg, E., Z. Chem., 4, 303 (1964).

[29] Stout, M.G. and Robins, R.K., J. Org. Chem., 33, 1219 (1968).

[30] Lemieux, R.U. and Hoffer, M., Can. J. Chem., 39, 110 (1961).

[31] Southon, I.W. and Pfleiderer, W., Chem. Ber., 111, 996 (1978).

[32] Sato, T., Shimadate, T., Ishido, Y. and Zasshi, N.K., J. Chem. Soc. Japan, 81, 1440 (1960). 


\section{تشييد وخصائص طيفية لمشتقات كينازولين دايون}

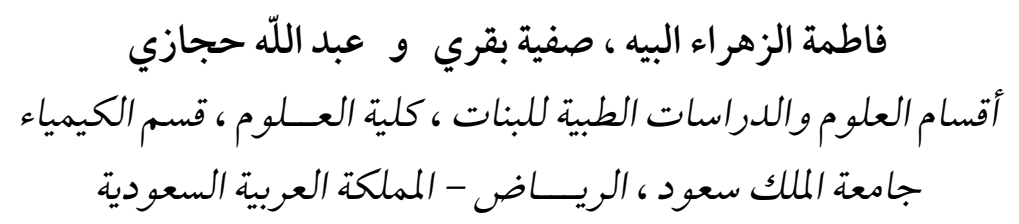

المستخلص . معاملة حمض الأثثرانيل ا وحمض ب-أمينو-Y-بافتالينه

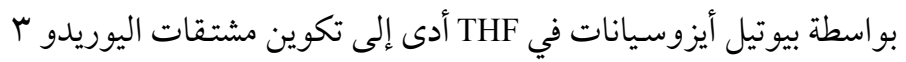

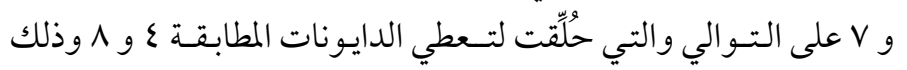

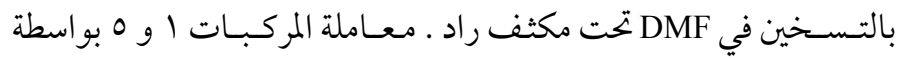

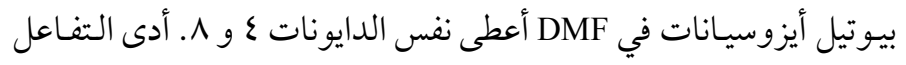

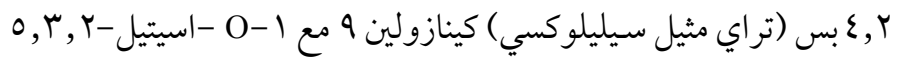

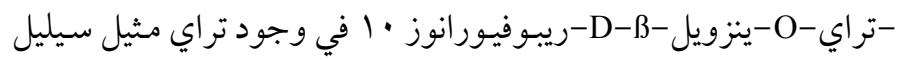

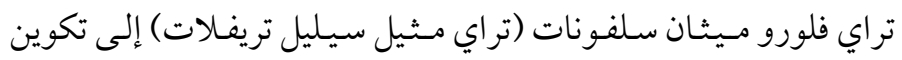

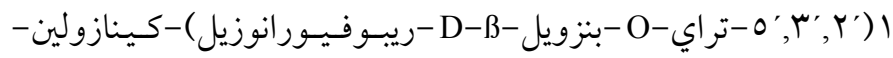

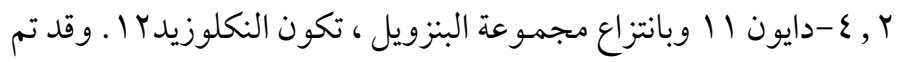

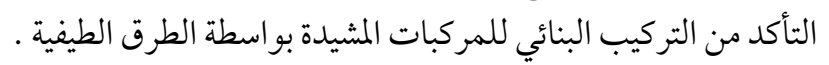

